\title{
Urban environmental quality and public policies for sustainable development as support for planning and development
}

\author{
EDITORIAL
}

Anderson Catapan

catapan@utfpr.edu.br

Universidade Tecnológica Federal
Paraná, Curitiba, Paraná, Brasil.

Antonio Gonçalves de Oliveira agoliveira@utfpr.edu.br

Universidade Tecnológica Federal do Paraná, Curitiba, Paraná, Brasil.
This editorial features articles from the third issue of the ninth volume of the Brazilian Journal of Planning and Development - Revista Brasileira de Planejamento e Desenvolvimento (RBPD). This issue has contributed to the planning and development, as in previous and usual numbers of this journal, by teachers from Brazil.

This issue contains important discussions on urban environmental quality, sustainability and urban planning, demand risk management, public policies, sustainable universities, among others.

We thank you for the contribution of all the authors and reviewers of our journal. Presented the articles of this issue, we wish a great and useful reading to all! 